\title{
IMPLEMENTASI PROBLEM BASED-LEARNING (PBL) DAN PENDEKATAN ILMIAH MENGGUNAKAN MEDIA KARTU UNTUK MENINGKATKAN HASIL BELAJAR PESERTA DIDIK TENTANG MENGAJAR IKATAN KIMIA
}

\author{
Ramlan Silaban ${ }^{1)}$; Freddy Tua Musa Panggabean ${ }^{2)}$; Felia Mutiara Hutapea ${ }^{3)}$; \\ Esrida Hutahaean ${ }^{4}$; Irving Josafat Alexander ${ }^{5)}$ \\ ${ }^{1}$ Jurusan Kimia, FMIPA Universitas Negeri Medan; drrsilabanmsi@ yahoo.co.id \\ ${ }^{2}$ Jurusan Kimia, FMIPA Universitas Negeri Medan; freddypanggabean234@yahoo.com \\ ${ }^{3}$ Bimbel Talenta Medan; feliahutapea@gmail.com \\ ${ }^{4}$ SMA Dharma Jaya Medan; esridahutahaean@gmail.com \\ ${ }^{5}$ Bimbingan Belajar Scholar Nasional Medan; irvingjosafat7@gmail.com
}

\begin{abstract}
This study aims to determine whether there is an influence on the implementation of PBL through a scientific approach that provides a media card for high school students' chemistry learning outcomes. To achieve this goal, quasi-experimental research was conducted using two classes, namely the experimental class and the control class. Data obtained using a validated test instrument in the form of pretest and posttest. The results showed that (1). There was an increase in chemistry learning outcomes from the average pretest 27.2 to 63.95 and 72.5 in the two classes of experiment I and experiment II, respectively. (2). Student learning outcomes that are taught with the Problem Based Learning model and the scientific approach provides higher paired cards than using textbook as a media.
\end{abstract}

Keywords: Problem Based Learning (PBL); Scientific Approac;Card media; Student Learning Outcomes

\begin{abstract}
ABSTRAK
Penelitian ini bertujuan untuk mengetahui apakah ada pengaruh pada implementasi PBL melalui pendekatan ilmiah yang menyediakan kartu media untuk hasil belajar kimia pesrta didik SMA. Untuk mencapai tujuan ini, penelitian eksperimen semu dilakukan dengan menggunakan dua kelas, yaitu kelas eksperimen dan kelas kontrol. Data diperoleh dengan menggunakan instrumen tes yang divalidasi dalam bentuk pretest dan posttest. Hasil penelitian menunjukkan bahwa (1). Ada peningkatan hasil belajar kimia dari pretest rata-rata 27,2 menjadi 63,95 dan 72,5 di dua kelas eksperimen I dan eksperimen II, masing-masing. (2) Hasil belajar pesrta didik yang diajarkan dengan model Pembelajaran Berbasis Masalah dan pendekatan ilmiah memberikan kartu berpasangan yang lebih tinggi daripada menggunakan buku teks sebagai media
\end{abstract}

Kata kunci: Problem Based Learning (PBL); Pendekatan Ilmiah; Media Kartu; Hasil Belajar Pesrta didik.

\section{PENDAHULUAN}

Pendidikan merupakan kegiatan mengoptimalkan perkembangan potensi, kecakapan, serta karakteristik pribadi peserta didik (Kurniawan, 2012). Dalam
UU No. 20 tahun 2003 dikatakan bahwa tujuan pendidikan di Indonesia adalah mengembangkan potensi peserta didik agar menjadi manusia yang beriman dan bertakwa kepada Tuhan Yang Maha Esa, berakhlak mulia, sehat, berilmu, kreatif, 
mandiri dan menjadi warga negara yang demokratis serta bertanggungjawab. Untuk mewujudkan hal tersebut tidaklah mudah, dibutuhkan kerjasama antara seluruh komponen-komponen yang termasuk kedalam lingkup pendidikan secara terus menerus. Pemerintah juga ikut campur tangan dalam hal pendidikan di Indonesia. Pemerintah telah berupaya melakukan perbaikan kurikulum. Kurikulum merupakan perangkat mata pelajaran yang diajarkan pada lembaga pendidikan. Pada Kurikulum 2013 proses pembelajaran menggunakan pendekatan saintifik (scientific approach) yang memiliki materi pembelajaran berbasis fakta atau fenomena dan mampu dijelaskan menggunakan logika juga mendorong dan membuat pesrta didik berpikir secara kritis, analitis dan tepat dalam memecahkan masalah (Silaban, 2018). Pada prakteknya, pendekatan saintifik ini sering tidak dilakukan. Berdasarkan pengalaman peneliti selama mengikuti kegiatan Magang 3, pembelajaran yang dilakukan sekolah yang telah menerapkan Kurikulum 2013 masih berpusat pada guru. Menurut Mulyasa (2016) dalam pembelajaran efektif dan bermakna, peserta didik perlu untuk dilibatkan secara aktif, karena merekalah pusat dari kegiatan pembelajaran serta pembentukan dari kompetensi dan karakter. Peserta didik tersebut haruslah dilibatkan kepada tanyajawab yang terarah dan mencoba mencari pemecahan terhadap berbagai masalah yang ada pada pembelajaran. Pendekatan saintifik terdiri dari $5 \mathrm{M}$, yaitu mengamati, menanya, mengumpulkan data, mengasosiasi, dan mengkomunikasikan yang harus terlihat selama pembelajaran berlangsung. Pendekatan saintifik dapat digunakan dalam pembelajaran kimia, khususnya pada materi ikatan kimia. Kimia merupakan cabang ilmu yang mempelajari tentang komposisi, struktur dan energi yang menyertai perubahan suatu zat. Mata pelajaran kimia memiliki pemahamanpemahaman yang cukup rumit sehingga membuat mata pelajaran ini sulit untuk dipahami dan membutuhkan kemampuan berpikir tingkat tinggi untuk memahaminya (Kean \& Middlecamp, 1985).

Pemahaman konsep dasar pada materi ikatan kimia sangatlah penting, karena dari konsep dasar tersebutlah semua ilmunya bergerak dan berkembang hingga luas. Materi ikatan kimia juga memiliki tingkat keabstrakkan yang tinggi, sehingga jika guru menggunakan metode pembelajaran yang tidak tepat, maka pesrta didik akan mengalami miskonsepsi. Sifat keabstrakannya inilah yang membuat materi ikatan kimia sering dianggap sulit untuk dipelajari oleh pesta didik. Pembelajaran berbasis masalah atau Problem Based Learning (PBL) merupakan salah satu model pembelajaran inovatif yang dapat 
memberi kondisi belajar aktif kepada pesrta didik. Model PBL, mempersiapkan pelajaran untuk berpikir kritis dan analitis, serta untuk menemukan dan menggunakan sumber belajar (Sumantri, 2015). Keberhasilan yang diharapkan ditentukan oleh beberapa faktor selain model dan pendekatan yang tepat dapat juga digunakan media pembelajaran, agar proses pembelajaran lebih menarik lagi dan menumbuhkan pesrta didik lebih aktif dapat dipadukan dengan media kartu berpasangan yang mana terdiri dari kartu soal dan kartu jawaban yang disesuaikan dengan materi pelajaran yang dapat memancing rasa ingin tahu dan usaha untuk menemukan pasangan kartunya (Nugraha \& Binadja, 2013).

Model pembelajaran Problem Based Learning (PBL) telah diteliti oleh beberapa peneliti terdahulu dan terbukti dapat meningkatkan hasil belajar pesrta didik, antara lain: Abdurrozak (2016) menyimpulkan bahwa 1) terdapat peningkatan kemampuan berpikir kreatif pesrta didik dengan menggunakan model PBL, 2) terdapat peningkatan hasil belajar pesrta didik dengan menggunakan model PBL, 3) kemampuan berpikir kreatif pesrta didik dengan menggunakan model PBL lebih baik daripada menggunakan model konvensional. Yola adhysta (2014) meneliti dan mendapatkan hasil yaitu peningkatan hasil belajar kimia pesrta didik yang menerapkan model Problem Based Learning (PBL) berbantu media kartu berpasangan lebih tinggi dibandingkan dengan model pembelajaran konvensional pada materi tata nama senyawa sebesar $69,31 \%$.

Menjadikan pelajaran kimia menjadi suatu hal yang menarik untuk dipelajari merupakan hal yang penting, karena akan memberikan kesan dan pengalaman belajar yang baik untuk pesrta didik. Pembelajaran yang melibatkan pesrta didik itu sendiri juga akan dapat meningkatkan hasil belajar pesrta didik. Dengan pembelajaran model PBL yang melalui pendekatan saintifik dan menggunakan media kartu berpasangan maka diharapkan hasil belajar pesrta didik menjadi lebih baik (Silaban, 2016).

\section{METODE PENELITIAN}

Penelitian ini dilakukan dengan menggunakan metode eksperimen semu (Quasi Eksperiment). Penelitian ini dilakukan di kelas X MIPA SMA Negeri 1 Lubuk Pakam yang terletak di Jalan Dr. Wahidin No. 1 Lubuk Pakam, Deli Serdang pada bulan Oktober - November 2019.

Populasi pada penelitian ini adalah seluruh pesrta didik kelas X MIPA tahun ajaran 2019-2020 dengan kurikulum 2013 yang belajar materi ikatan kimia.Pengambilan sampel kelas dilakukan dengan metode purposive sampling, banyaknya sampel yang digunakan pada 
penelitian ini adalah sebanyak 2 kelas. Sampel 1 dijadikan kelas eksperimen I yang diajarkan dengan model pembelajaran PBL melalui pendekatan saintifik dengan media buku yang telah ada di sekolah. Sampel 2 dijadikan kelas eksperimen II yang diajarkan dengan model pembelajaran PBL melalui pendekatan saintifik dengan media kartu berpasangan.

\section{Variabel penelitian}

Pada penelitian ini digunakan tiga macam variabel, yaitu :

\section{Variabel bebas}

Variabel bebas dalam penelitian ini adalah penggunaan model pembelajaran Problem Based Learning melalui pendekatan saintifik dengan menggunakan media kartu berpasangan.

\section{Variabel terikat}

Variabel terikat dalam penelitian ini adalah hasil belajar pesrta didik pada materi Ikatan kimia.

\section{Variabel kontrol}

Variabel kontrol dalam penelitian ini adalah materi yang diajarkan, buku pegangan pesrta didik, guru yang mengajar, kurikulum, jumlah jam pelajaran, dan soal pretest dan postest yang sama.

Penelitian ini dilaksanakan dalam tiga tahap yaitu : (1) Tahap persiapan penelitian, (2) Tahap pelaksanaan penelitian, (3) Tahap pengolahan Data.
Pada penelitian iniinstrument yang digunakan, yaitu instrumen tes. Instrumen tes yang digunakan adalah soal berbentuk pilihan berganda sebanyak 40 soal yang selanjutnya dihitung validitas dan reliabilitasnya. Tes hasil belajar pesrta didik yaitu pretes dan postest sebanyak 20 soal dari 40 soal yang telah diuji validitasnya

\section{Teknik Analisis Data}

Pada penelitian ini, instrumen yang digunakan akan dianalisis dari segi tingkat kesukaran, daya pembeda, validitas, dan reliabilitas.

\section{Pengujian Hipotesis}

Pengujian hipotesis dilakukan dengan Uji Pihak kanan untuk melihat apakah Ha memiliki hasil lebih tinggi atau tidak, jika $\mathrm{n} 1 \neq \mathrm{n} 2$

$$
\mathrm{t}_{\mathrm{hit}}=\frac{(\overline{X 1}-\overline{X 2})}{s p \sqrt{\frac{1}{n 1}}+\frac{1}{n 2}}
$$

Dimana,

$$
\mathrm{SP}=\sqrt{\frac{(n 1-1) S 1^{2}+(n 2-1) S 2^{2}}{n 1+n 2-2}}
$$

\section{HASIL DAN PEMBAHASAN}

Pada penelitian yang dilakukan, sebelum kedua kelas sampel diberikan perlakuan yang berbeda yaitu model PBL dengan pendekatan saintifik menggunakan media buku yang telah ada di sekolah pada kelas eksperimen I dan model PBL dengan pendekatan saintifik menggunakan media kartu berpasangan pada kelas eksperimen 
II terlebih dahulu diberikan tes awal atau pretest yang bertujuan untuk mengetahui kemampuan awal masing-masing peserta didik pada kedua kelas penelitian, serta untuk mengetahui apakah kedua kelas tersebut terdistribusi normal dan homogen atau tidak.

Selanjutnya dilakukan pembelajaran yang berbeda yaitu kelas eksperimen I dibelajarkan dengan model PBL dan pendekatan saintifik menggunakan media buku yang telah ada di sekolah dan kelas eksperimen II dibelajarkan dengan model PBL dan pendekatan saintifik menggunakan media kartu berpasangan. Pada akhir proses pembelajaran akan diberikan tes akhir atau post-test untuk mengetahui hasil belajar pesrta didik. Berdasarkan hasil perhitungan diperoleh data statistik hasil belajar pesrta didik pada kelas eksperimen I dan kelas eksperimen II yang dirangkum dalam tabel statistik deskriptif hasil belajar pesrta didik kelas eksperimen I dan kelas eksperimen II pada tabel 1:

Tabel 1.Rangkuman Statistik Deskriptif Hasil Belajar Pesrta Didik

\begin{tabular}{cccc}
\hline Data & Statistik & $\begin{array}{c}\text { Kelas } \\
\text { eksperimen } \\
\text { 1 }\end{array}$ & $\begin{array}{c}\text { Kelas } \\
\text { eksperimen } \\
\mathbf{2}\end{array}$ \\
\hline & Nilai Total & 600 & 540 \\
& & & \\
\cline { 2 - 4 } Pre- & Rata-rata & 27,5 & 27 \\
Test & Varians & 58,69 & 93,15 \\
\cline { 2 - 4 } & S. Deviasi & 7,66 & 9,65 \\
\cline { 2 - 4 } & Nilai & 40 & 45 \\
& Maks. & & \\
\cline { 2 - 4 } Post- & Nilai Min. & 10 & 5 \\
\cline { 2 - 4 } Nest & Rilai Total & 1535 & 1450 \\
\hline & Rata-rata & 63,95 & 72,5
\end{tabular}

\begin{tabular}{ccc}
\hline Varians & 152,12 & 146,05 \\
\hline S. Deviasi & 12,33 & 12,08 \\
\hline $\begin{array}{c}\text { Nilai } \\
\text { Maks. }\end{array}$ & 90 & 90 \\
\hline Nilai Min. & 40 & 45
\end{tabular}

Berdasarkan tabel 1, maka dapat digambarkan perbedaan hasil perolehan rata-rata nilai pre-test dan post-test kelas eksperimen I dan kelas eksperimen II melalui diagram pada gambar 1

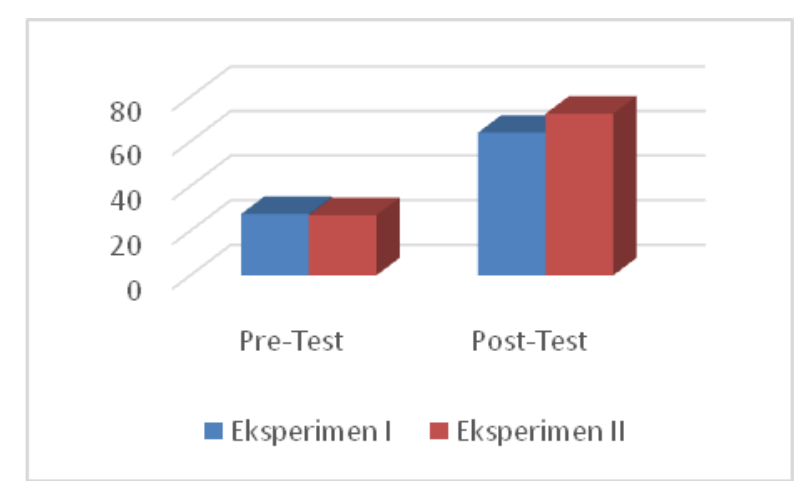

Gambar 1.Diagram hasilbelajar Ikatan kimia Pre-Test dan Post-Test pesrta didik

Berdasarkan gambar 1 bahwa hasil post-test kelas eksperimen II lebih tinggi dibandingkan hasil post-test kelas eksperimen I. Hasil post-test merupakan nilai hasil belajar pesrta didik sedangkan hasil pre-test untuk mengukur kemampuan awal pesrta didik sehingga dapat ditentukan homogenitas dan normalitas kelas tersebut.

Pada prasyarat analisis data yang dilakukanuntuk mengetahui normalitas dari data penelitian, disajikan dalam tabel 2. Uji normalitas data menggunakan uji Chi kuadrat pada taraf nyata $\alpha=0,05$ dengan kriteria Chi Kuadrat $X^{2}$ hitung

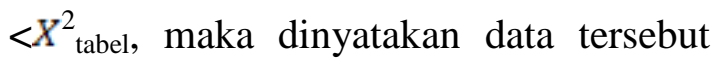


berdistribusi normal. Hasil perhitungan $X^{2}$ kelas eksperimen I dan kelas eksperimen II disajikan dalam tabel 2.

Tabel 2.Uji normalitas data

\begin{tabular}{cccccc}
\hline Kelas & Data & $\boldsymbol{X}_{\text {hitung }}$ & $\boldsymbol{X}_{\text {tabel }}{ }^{2}$ & $\boldsymbol{\alpha}$ & Ket. \\
\hline \multirow{2}{*}{$\begin{array}{c}\text { Eksper } \\
\text { imen I }\end{array}$} & $\begin{array}{c}\text { Pre- } \\
\text { test }\end{array}$ & 6,28 & 11,07 & 0,05 & Normal \\
\cline { 2 - 6 } & $\begin{array}{c}\text { Post- } \\
\text { test }\end{array}$ & 4,85 & 11,07 & 0,05 & Normal \\
\hline \multirow{2}{*}{$\begin{array}{c}\text { Eksper } \\
\text { imen II }\end{array}$} & $\begin{array}{c}\text { Pre- } \\
\text { test }\end{array}$ & 5,42 & 11,07 & 0,05 & Normal \\
\cline { 2 - 6 } & $\begin{array}{c}\text { Post- } \\
\text { test }\end{array}$ & 8,42 & 11,07 & 0,05 & Normal \\
\hline
\end{tabular}

Pada tabel 2 menunjukan bahwa Nilai pre-test dan post-testdari kedua kelas sampel tersebut berdistribusi normal pada taraf 0,05 dengan $X_{\text {tabel }}^{2}=$ 11,07 .

Selanjutnya homogenitas data penelitian disajikan dalam tabel 3. Uji homogenitas data sampel pada kelas eksperimen I dan eksperimen II dengan menggunakan Uji $\mathrm{F}$ pada taraf nyata $\alpha=$ 0,05 dengan kriteria $F_{\text {hitung }}<F_{\text {tabel, }}$ maka dinyatakan data tersebut homogen.

Tabel 3.Uji homogenitas data

\begin{tabular}{ccccccc}
\hline Ke & Ter & Data & $\boldsymbol{F}_{\text {hitun }}$ & $\boldsymbol{F}_{\text {tabel }}$ & $\boldsymbol{\alpha}$ & Ket. \\
las & $\begin{array}{c}\text { had } \\
\text { ap }\end{array}$ & & $\mathrm{g}$ & & & \\
\hline Ek & Eks & Pre- & 1,587 & 1,995 & 0,05 & Hom \\
spe & peri & test & & & & ogen \\
\cline { 3 - 6 } rim & men & Post- & 1,034 & 1,995 & 0,05 & Hom \\
en & I & test & & & & ogen \\
I & & & & & & \\
\hline
\end{tabular}

Berdasarkan table 3 dapat dilihat bahwa nilai pre-test dan post-testdari kedua kelas sampel tersebut pada taraf $\alpha=$
0,05 adalah homogen, dengan $\mathrm{F}(0,05)$ $(19,23)=1,995$.

Setelah melakukan uji prasyarat analisis data dan telah menarik kesimpulan bahwa data berdistribusi normal dan homogen, maka dilaksanakan pengujian terhadap hipotesis dalam penelitian, untuk pengujian hipotesis dilakukan dengan menggunakan uji t-pihak kanan.

\section{Pengujian Hipotesis}

Kriteria pengujian jika $t_{\text {hitung }}>t_{\text {tabel }}$ maka tolak Ho, sehingga Ha diterima. Data hasil uji hipotesis disajikan dalam tabel 4.

Tabel 4.Uji hipotesis hasil belajar

\begin{tabular}{|c|c|c|c|c|c|}
\hline Kelas & $\bar{X}$ & $S^{2}$ & $T_{\text {hit }}$ & $T_{\text {tabel }}$ & Ket. \\
\hline $\begin{array}{l}\text { Eksper } \\
\text { imen I }\end{array}$ & 63,95 & $\begin{array}{c}162,3 \\
0\end{array}$ & 2,275 & 1,682 & $\begin{array}{c}\text { Tolak } \\
\text { Ho, Ha }\end{array}$ \\
\hline $\begin{array}{l}\text { Eksper } \\
\text { imen I }\end{array}$ & 72,5 & $\begin{array}{c}145,9 \\
2\end{array}$ & & & diterima \\
\hline
\end{tabular}

Data distribusi $\mathrm{t}$ (tabel 4) diperoleh $\mathrm{t}$ tabel interpolasi $=1,682$ sedangkan perhitungan diperoleh thitung $=2,275$ sehingga harga $t_{\text {hitung }}>t_{\text {tabel }}$, maka tolak Ho dan $\mathrm{Ha}$ diterima sehingga disimpulkan bahwa hasil belajar kimia pesrta didik yang dibelajarkan model Problem Based Learning menggunakan media kartu berpasangan melalui pendekatan saintifik lebih tinggi dari pesrta didik yang dibelajarkan dengan model Problem Based Learning menggunakan media buku melalui pendekatan saintifik pada materi ikatan kimia. 
Jika dibandingkan dengan hasil penelitian yang dilakukan oleh Yola adhysta (2014) yang menghasilkan bahwa peningkatan hasil belajar kimia pesrta didik yang menerapkan model Problem Based Learning (PBL) berbantu media kartu berpasangan lebih tinggi dibandingkan dengan model pembelajaran konvensional pada materi tata nama senyawa, makakedua penelitian ini sejalan. Selain itu penelitian ini juga mendukung penelitian yang dilakukan oleh Sudewi (2014) yang menyatakan bahwa hasil belajar pesrta didik kelompok PBL lebih tinggi daripada kelompok GI (Group Investigation). Penelitian Nasution (2017) juga mengatakan bahwa terdapat peningkatan hasil belajar kimia pesrta didik yang dibelajarkan dengan menggunakan model pembelajaran saintifik pada pokok bahasan ikatan kimia.

\section{SIMPULAN DAN SARAN}

\section{SIMPULAN}

Ada peningkatan hasil belajar kimia pesrta didik yang dibelajarkan menggunakan model Problem Based Learning (PBL) dan Pendekatan Saintifik bermediakan Kartu dari ratarata pretes 27.2 menjadi 63.95 and 72.5 di kedua kelas eksperimen dan hasil belajar kimia pesrta didik yang dibelajarkan menggunakan PBL dan Pendekatan Saintifik bermediakan Kartu Berpasangan lebih tinggi dari bermediakan Buku Teks Kimia.

\section{SARAN}

Model Problem Based Learning diharapkan dapat digunakan dengan pendekatan Saintifik pada materi ikatan kimia.

\section{UCAPAN TERIMAKASIH}

Terimakasih kepada Pimpinan Unimed atas pelaksanaan penelitian ini, kepada Kepala Sekolah dan jajarannya, ibu Friska Sihombing, S.Pd. guru mata pelajaran Kimia SMA Negeri 1 Lubuk Pakam beserta seluruh pihak yang turut berperan dalam penelitian ini.

\section{Daftar Pustaka}

Abdurrozak, R., Jayadinata, A. K., \&Atun,I., (2016), Pengaruh Model Problem Based Learning TerhadapKemampuan Berpikir Kreatif Pesrta didik, Jurnal Pena Ilmiah, 1(1): 871-880;

Adhysta, Y., (2014), Pengaruh Penerapan Model Problem Based Learning $(P B L) \quad$ Berbantu Media Kartu Berpasangan terhadap hasil Belajar Pesrta didik padaMateri Tata Nama Senyawa, Skripsi, FMIPA, UNIMED;

Kean, E \& Middlecamp, C.,(1985), Panduan Belajar Kimia Dasar, PT. Gramedia. Jakarta;

Kurniawan, E. (2012), Perbedaan Metode Brain Based Learning terhadap Capaian Prestasi Akademik dan Retensi Pengetahuan Pesrta didik pada Pembelajaran Fisika di Sekolah Menengah Pertama, Skripsi,Universitas Islam Negeri Sunan Kalijaga;

Mulyasa, H., (2016), Pengembangan dan Implementasi Kurikulum 2013, Rosdakarya Bandung; 
Nasution, F. (2017). Penerapan Pendekatan Pembelajaran Saintifik Terhadap Hasil Belajar Kimia Pesrta didik Kelas X di SMA Swasta PersiapanStabat (Doctoral dissertation, UNIMED);

Nugraha, D. A., \& Binadja, A., (2013), Pengembangan Bahan Ajar Reaksi Redoks Berbasis SETS Berorentasi Konstruktivistik, Journal of Innovatve Science Education, 2(1) : 27-34;

Silaban, R., Mahmud, Atmaja G. Adawiyah, R. (2018), Analysis of teaching materials and learning science based on Curriculum 2013, IOSR Journal of Research and Method in Education, 8 (3), pp 7076 ;
Silaban, R., Pasaribu, M., Sitompul SMF, Simanullang, TW. (2016), Inovasi Lembar Kerja Pesrta didik Reaksi Redoks Berbasis Pemecahan Masalah untuk Pesrta didik SMA; Jurnal Pendidikan Kimia, 8 (1), 65-70;

Sudewi, N. L., Subagia, I. W., \& Tika, I. N., (2014), Studi Komparasi Penggunaan Model Pembelajaran Problem Based Learning (PBL) dan Kooperatif Tipe Group Investigation (GI) Terhadap Hasil Belajar Berdasarkan Taksonomi Bloom, e-Journal Program Pascasarjana Universitas Pendidikan Ganesha 4;

Sumantri,M.S, (2015), Strategi Pembelajaran, Rajawali Press. Jakarta. 